\title{
PENGARUH KONSELING INDIVIDUAL DENGAN PENDEKATAN CLIENT CENTERED TERHADAP ETIKA BERGAUL SISA DI KELAS X IPA 2 SMAN 4 MEDAN
}

\author{
Linda Andriani Sirait \\ Prof. Dr. Asih Menanti, MS.,S.Psi \\ Jurusan PPB Prodi Bimbingan dan Konseling FIP UNIMED
}

\begin{abstract}
Abstrak
Tujuan penelitian ini adalah untuk mengetahui pengaruh layanankonselingindividual dengan pendekatan client centered terhadap Etika Bergaul siswa di kelas X IPA 2 SMA Negeri 4 Medan Tahun Ajaran 2017/2018. Rumusan masalah dalam penelitian ini adalah: apakah ada pengaruh layanan konseling individual dengan pendekatan client centeredterhadap Etika Bergaul siswa kelas X IPA 2 SMA Negeri 4 Medan Tahun Ajaran 2017/2018. Metode yang digunakan dalam penelitian ini adalah metode kuantitatif. Jenis penelitian ini adalah Pra Eksperimen dengan one group pre-test dan post-test design. Subjek dalam penelitian ini adalah 3 orang siswa kelas X IPA 2 yang memiliki skor terendah yang telah dibagi angket etika bergaul siswa, dan akan diberikan layanan konseling individual dengan pendekatan client centered. Hasil analisis diperoleh dat pre-test siswa rata-rata = 228 termasuk katagori tinggi dan Standart Deviasi $(\mathrm{SD})=4,358$, sedangkan hasil data post-test ratarata $=$ termasuk kategori rendah dan Standart Deviasi $(\mathrm{SD})=7,57$. Teknik uji hipotesis menggunakan rumus uji Wilxocon yang memperoleh hasil $\mathrm{T}_{\text {hitung }}=4,55$ sedangkan harga $\mathrm{T}_{\text {tabel }}=3,182$. Dari tabel nilai kritis T utuk uji jenjang bertanda wilcoxon untuk $\mathrm{n}=3, \alpha=0,05$ sesuai dengan kriteria penerimaan dan penolakan hipotesis, hipotesis diterima jika Thitung $>$ Ttabel. Dengan demikian dinyatakan ada pengaruh layanan konselingindividual dengan pendekatan client centered terhadap Etika Bergaul siswa di kelas X IPA 2 SMA Negeri 4 Medan Tahun Ajaran 2017/2018. Dengan demikian hipotesis diterima
\end{abstract}

Kata Kunci : Konseling Individual; Pendekatan Client Centered;Etika Bergaul

\section{PENDAHULUAN}

Remaja merupakan masa peralihan untuk menuju kedewasaan dengan pertumbuhan dan perkembangan selanjutnya sehingga mampu bertanggung jawab terutama dalam pergaulan remaja, baik itu dalam lingkungan tempat tinggal, sekolah dan masyarakat luas termasuk dalam etika. Pada masa remaja, individu harus mulai dapat bertanggung jawab mengendalikan perilakunya yang sebelumnya pada masa kanak-kanak menjadi tanggung jawab orang tua dan guru, sehingga perilakunya tidak melanggar moral yang berlaku.

Norma atau etika merupakan patokan perilaku dalam suatu kelompok tertentu. Dalam setiap kegiatan manusia yang melibatkan hubungan antar personal sudah pasti diperlukan sejumlah normal dan etika,selain untuk mengatur perilaku norma juga dibuat untuk memelihara dan meningkatkan ketertiban diantara individuindividu yang memiliki kepentingan yang berbeda. Dengan adanya norma dan etika seseorang tidak dapat berbuat semaunya. Kata "Etika" berasal dari kata "ethos" 
(bahasa Yunani), sedangkan kata "moral" berasal dari kata "mos" jamaknya "mores" (bahasa Latin). Arti kata "etika" dan "mores" pada asalnya sama yakni "kebiasaan atau cara hidup" (Poedjawijatna, 1982:14).

Dalam setiap pergaulan, baik masyarakat, berbangsa, bahkan sampai kedunia internasional, dibutuhkan suatu etikan sebagai alat menilai baik-buruknya suatu tindakan. Dalam duni pendidikan, etika meerupakan hal yang paling mendasar yang menjadi pegangan manusia dalam bersosialisasi dengan masyarakat.

Di dalam pendidikan SMA, kawasan yang harus diperhatikan adalah etika bergaul, karena ketika anak/siswa sudah mengembangkan etika pergaulan, maka siswa dapat membedakan mana yang baik dan buruk, kemudian mereka terapkan dalam kehidupan sehari-hari dan akan berpengaruh pada lingkungan sekitarnya dalam bersosialisasi.

Seiring dengan perkembangan zaman semakin lama etika tersebut semakin luntur, termasuk pada kalangan siswa SMA. Sebagian siswa biasanya memiliki karakter menentang nilai dan norma yang ada dimasyarakat. Salah satu sikap siswa yang menentang etika adalah siswa yang mulai bergaul baik dalam cara berpakaian yang tidak rapi, cara tutur kata pada teman yang menghiraukan kesopanan pada etika.
Masalah etika adalah, masalah manusia pada umumnya dimanapun manusia berada dalam komunitasnya, pasti etika dan etika ikut berperan sebagai pedoman tingkah laku baik buruk dalam pergaulan. Remaja yang merupakan bagian dari manusia memerlukan pedoman tingkah laku agar pergaulan sesama remaja dapat berjalan dengan baik sesuai dengan norma masyarakatnya atau sesuai dengan norma agama yang dianutnya, sehingga mereka terhindar dari pergaulanyang menyimpang yang tidak sesuai dengan norma masyarakat dan norma agama.

Berdasarkan hasil observasi yang dilakukan oleh peneliti di SMA Negeri 4 Medan pada bulan April Tahun 2017 dikelas X IPA 2 terdapat $75 \%$ siswa dari 35 siswa. Hal tersebut terlihat pada perilaku siswa di kelas yang berkurang mencerminkan etika pergaulan yang baik seperti siswa kurang memiliki etika bergaul yang baik, tata krama dan sopan santun siswa pada guru kurang, tata cara berbicara siswa tidak menaati peraturan sekolah, cara berpakaian siswa yang tidak sopan.

Untuk menyadarkan akan pentingnya etika dalam pergaulan, maka layanan konseling individual dengan menggunakan pendekatan client centered dianggap tepat untuk memberikan topik berkaitan dengan mengurangi etika dalam pergaulan siswa. Menurut Willis (2011) 
layanan konseling individual merupakan layanan yang diselenggaran oleh seseorang guru Bimbingan dan Konseling (Konselor) terhadap seseorang konseli (siswa) dalam rangka penentasan masalah pribadi konseli. Dalam suasana tatap muka dilaksanakan interaksi langsung antara konseli dan konselor, membahas berbagai hal tentang masalah yang dialami konseli.

Carl R. Rogers dalam Corey (2010:91) menjelaskan terapi client centered sebagai : "Reaksi terhadap apa yang dibutuhkannya keterbatasanketerbatasan mendasar dari psikoanalisis. Pada hakikatnya, pendekatan client centered adalah cabang khusu dari terapi humanistik yang mengaris bawahi tindakan yang dialami klien berikut dunia subjektif dan fenomenalny. Terapis berfungsi terutama sebagai penunjang pertumbuhan pribadi kliennya itu dengan jalan membantu kliennya itu dalam menemukan kesanggupan-kesanggupan untuk memecahkan masalah-masalah.”

Pendekatan client centered menaruh kepercayaan yang besar pada kesanggupan klien untuk mengikuti terapi dan menemukan arahnya sendiri. Hubungan dalam pendekatan client centered antara terapi dan klien merupakan hasil bagi perubahan klien secara baik, menggunakan hubungan yang unik sebagai nalat untuk meningkatkan kesadaran dan untuk menemukan sumber-sumber terpendam yang bisa digunakan secara konstruktif dalam pengubahan hidupnya.

\section{KAJIAN PUSTAKA}

Etika pergaulan adalah perilaku sopan santun atau tata krama dalam pergaulan yang sesuai dengan situasi dan keadaan serta tidak melanggar normanorma yang berlaku baik norma kesopanan, adat hukum dan lain-lain. Etika pergaulan yang dipengaruhi oleh 4 faktor yaitu : Lingkungan, adat istiadat pendidikan dan genetika.

Dengan konseling individual client centered adalah konseling tatap muka yang dilakukan secara pribadi antara konseli dan konselor yang menitik beratkan proses konseling kepada klien dalam mengentaskan masalahnya. Pendekatan client centered difokuskan pada tanggung jawab dan kesanggupan klien untuk menemukan cara-cara menghadapi kenyataan secara lebih penuh. Klien sebagai orang yang paling mengetahui dirinya sendiri adalah orang yang harus menemukan tingkah laku yang lebih pantas bagi dirinya. Pendekatan client centered menekankan dunia fenomena klien. Dengan konseling individual pendekatan client centered dapat terjadi perubahan meningkat etika pergaulan siswa kelas X IPA 2 menjadi pribadi yang lebih baik . 


\section{METODE PENELITIAN}

Adapun jenis dari penelitian ini adalah Pra Eksperimen. Menurut Menanti Asih (2013:79) Pra Eksperimen adalah Eksperimen yang ditandai oleh tidak ada kelompok kontrol dan tidak ada randomnisasi. Perlakukan diberikan kepada kelompok yang telah terbentuk apa adanya.

Desain yang digunakan dalam penelitian ini adalah menggunakan desain one group pre-test dan post-test design. Menurut Arikunto (1992) desain one group pre-test dan post-test design.

Populasi penelitian ini adalah seluruh siswa kelas $\mathrm{X}$ IPA 2 di SMA Negeri 4 Medan Tahun Ajaran 2017/2018 yang berjumlah 30 siswa. Subjek dalam penelitian ini adalah 3 orang siswa yang memiliki etika bergaul rendah yang diberikan angket etika bergaul.

Teknik analisis data adalah cara yang dilakukan untuk mengelola data penelitian dalam mencapai penelitian. Teknik analisis data berkenaan dengan pengelolahan data penelitian. Dalam hal ini suatu pekerjaan menyusun dan mengorganisasikan data, membuat tabeltabel data menurut masa-masanya, seperti tabel distribusi frekuensi, tabel kontigensi, adapun teknik analisis data yang digunakan adalah dengan menggunakan uji wilcoxon (Sudjono,2002: 450) yaitu untuk melihat apakah ada pengaruh konseling kelompok individu etika bergaul siswa sebelum dan sesudah diberikan perlakuan. Dalam uji wilcoxon, bukan saja tanda yang diberikan tetapi juga nilai selisih (X:Y).

Langkah-langkah yang dilakukan dalam wilcoxon sebagai berikut:

a. Memberi nomor untuk harga mutlak selisih $\left(\mathrm{X}_{\mathrm{i}}-\mathrm{Y}_{\mathrm{i}}\right)$. Harga mutlak yang terkecil diberi nomor urut atau peringkat 1, harga untuk selisih berikutnya diberi nomor 2, dan akhirnya harga mutlak terbesar diberi nomor urut $\mathrm{n}$. Jika terdapat selisih yang harga mutlaknya sama besar.

b. Untuk nomor urut diambil rataratanya. Untuk tiap nomor urut diberikan pula tanda yang didapat dari selisih $(\mathrm{X}-\mathrm{Y})$.

c. Hitunglah jumlah nomor urut yang bertanda positif dan juga jumlah nomor urut yang bertanda negatif.

d. Untuk jumlah nomor urut yang didapat pada poin c, ambillah jumlah harga mutlaknya yang paling kecil, sebutlaj jumlah ini sama dengan J, jumlah $\mathbf{J}$ ini yang dipakai untuk menguji hipotesis. $\mathrm{H}_{0}$ : tidak ada perbedaan pengaruh kedua perlakuan

$\mathrm{H}_{\mathrm{i}}$ : terdapat perbedaan pengaruh kedua perlakuan

Kriteria pengujian :

$\mathrm{H}_{0}$ diterima jika $\mathrm{j}_{\text {hitung }}>\mathrm{J}_{\text {tabel }}$ dan akan ditolak jika jhitung $<\mathrm{J}_{\text {tabel. }}$ untuk menguji pengaruh yang signifikan layanan 
konseling individual pendekatan client centered dalam mengurangi etika bergaul negatif siswa maka harga tersebut dikonsultasikan ke tabel nilai distribusi dengan $\mathrm{j}_{\text {hitung }}>\mathrm{J}_{\text {tabel }}$ dengan tarif signifikan $\alpha=0,05$ dan $\mathrm{db}=\mathrm{N}-1$, maka pengaruh tersebut dinyatakan signifikan.

Penelitian ini dilakukan di SMA Negeri 4 Medan yang berada dijalan Gelas No. 12, Sei Putih Tengah, Medan Petisah, Kota Medan.

\section{HASIL DAN PEMBAHASAN PENELITIAN}

Data dalam penelitian ini diperoleh dengan melakukan pengukuran terhadap Etika bergaul siswa dengan pemberian angket sebelum melakukan layanan konseling individual pendekatan client centered (pre-test) dan setelah melaksanakan layanan konseling individual pendekatan client centered (post-test). Selanjutnya data-data ini diolah dengan tahapan mulai dari deskripsi data, pengujian persyaratan analisis, dan pengujian hipotesis.

Penelitian ini dilakukan di SMA Negeri 4 Medan yang beralamat di Jalan Gelas No.12, kelurahan Sei Putih Tengah kecamatan Medan Petisah, Kota Medan.

Pada awalnya penelitian melakukan wawancara dengan guru BK di sekolah untuk mendapatkan data siswa yang memiliki etika bergaul, dan setelah mendapatkan data hasil dari guru BK, peneliti memutuskan untuk mengambil kelas $\mathrm{X}$ MIPA 2 karena dari hasil wawancara merupakan kelas yang memiliki etika bergaul karena menunjukkan ciri-ciri anggota kelasnya sering saling mengejek, kurang menghargai, kurang disiplin bahkan sering berkelahi. Setelah mendapatkan data, peneliti meguji coba angket yang yang telah di[ersiapkan kepada siswa kelas $\mathrm{X}^{\mathrm{MIPA7}}$ yang berjumlah 36 siswa.

Selanjutnya peneliti memberikan angket yang telah valid dikelas $\mathrm{X}^{\text {MIPA2 }}$ yang berjumlah 30 orang sebagai tahap untuk penentuan sampel penelitian dan untuk mengetahui sejauh mana tingkat etika bergaul siswa dikelas tersebut. Dan dari hasil pemberiann angket tersebut, peneliti memperoleh data etika bergaul siswa yang berbeda-beda. Langkah selanjutnya penelitipun mengkategorikan siswa berdasarkan hasil skoring angket, maka diperoleh hasil yaitu 3 responden kategori rendah, 16 responden kategori sedang, 11 respondedn kategori tinggi. Sehingga peneliti memutuskan megambil 3 siswa yang menjadi sampel penelitian untuk diteliti selanjutnya.

Berdasarkan hasil angket yang diperoleh dari pelaksanaan pre-test angket penelitian dengan jumlah responden 3 siswa diperoleh hasil sebagai berikut: Skor terendah: 71, skor sedang: 78, skor tertinggi: 79 dengan rata-rata skor angket 
76. Yang memiliki peningkatan sebesar $40 \%$ setelah dilakukan konseling individual. Berdasarkan data yang diperoleh dari pelaksanaan Post test angket penelitian dengan jumlah responden 3 siswa yang sama diperoleh hasil sebagai berikut: skor terendah: 102, skor tertinggi: 116, rata-rata: 107.

Berdasarkan tahapan yang dikemukakan Willis (2010:64) mengemukakan langkah-langkah konseling individual yaitu tahapan awal, tahapan inti, dantahapan akhir. Maka peneliti sudah melaksanakan tahapan dengan baik. D engan adanya tahapantahapan dalam konseling individual maka konseling iindividual yang dilakukan berjalan lebih terarah.

Demikan pula yang dikemukakan oleh Nurwidiatno (2005:1) yang menyatakan bahwa etika pergaulan adalah sopan santun dalam pergaulan, yang banyak memberikan manfaat yaitu: sikap sopan santun membuat kita disayang oleh anggota keluarga, teman-teman, dan masyarakat tempat tinggal, sikap sopan santun membuat seseorang mempunyai banyak teman dan memiliki pergaulan luas sopan santun membuat orang lain atau masyarakat akan menilai pribadi seseorang dari sikap sopan santun yang kita miliki, sopan santun juga dapat menuntukan keberhasilan kita dalam hubungan kemasyarakatan.
Melalui penyaringan skor angket etika bergaul maka ditemukan 3 orang sampel yang akan diberikan tindakan berupa konseling individual dengan pendekatan client centered terjadi perubahan pada siswa sehingga dapat dikatakan penerapan konseling individuak dengan pendekatan client centered berhasil dilakukan.

Dengan demikian terbukti konseling individual dengan pendekatan client centered yang dikembangkan oleh Carl Ranson Rogers (dalam Sofyan S Willis 2014:64) dapat membantu menyelesaikan masalah siswa terutama masalah etika bergaulnya. Hal ini sejalan pula dengan tujuan pengadaan konseling individual dengan pendekatan client centered untuk membina keprinadian klien secara integral, berdiri sendiri, dan mempunyai kemampuan untuk memecahkan masalah sendiri. Tujuan konseling individual yang dikemukakan oleh Prayitno (2002:4) mengemukakan bahwa ada 2 tujuan konseling individual antara lain :Tujuan umum layanan konseling individual adalah pengrntasan masalah klien. Dengan demikian fungsi pengentasan sangat dominan dalam layanan ini. Dan tujuan khusus dalam layanan konseling individual ini adalah (1) klien dapat memahami seluk beluk masalah yang dialami secara mendalam dan komperhemsif, serta positif dan 
dinamis, (2) dikembangkannya persepsi dan sikap serta keinginan demi terentaskannya secara spesifik masalah yang dialami oleh klien itu. (3) pengembangan dan pemeliharan potensi klien dan berbagai unsur positif yang ada pada dirinya merupakan latar belakang pemahaman dan mengentaskan masalah klien dapat dicapai, (4) mencegah menjalarnya masalah yang sekarang sedang dialami oleh klien, serta (diharapkan) tercegah pula masalahmasalah baru yang mungkin timbul, (5) menangani sasaran yang bersifat advokasi.

Dari hasil perhitungan uji hipotesis pada siswa yang mengikuti bimbingan kelompok diperoleh dari perhitungan dengan hitung $t$ hitung $(4,55)>t$ tabel (3,182). Ini berarti $\mathrm{H}_{a}$ diterima dan $\mathrm{H}_{0}$ ditolak. Sehingga dapat disimpulkan bahwa " ada pengaruh pemeberian layanan konseling individual terhadapat etika bergaul siswa kelas XMIPA 2 SMAN 4 MEDAN.

Berdasarkan angket tersebut telah terbukti bahwa pemberian layanan konseling individual mempunyai pengaruh yang cukup signifikan terhadap etika bergaul siswa.

\section{PENUTUP}

\section{Kesimpulan}

Berdasarkan hasil penelitian yang telah dilaksanakan oleh peneliti, maka diperoleh kesimpulan bahwa ada pengaruh yang signifikan dalam pemberian konseling individual pendekatan client centered untuk meningkatkan etika bergaul siswa kelas X MIPA 2 di SMA Negeri 4 Medan.

Hal ini berdasarkan sebelum diberikan layanan konsling individual dengan pendekatan client centereddi dapatkan hasil rata-rata Pre-test (M) sebesar 76 dan setelah pemberian layanan konseling individual pendekatan client centered di dapatkan hasil rata-rata post test $(\mathrm{M})$ sebesar 107 yang berarti terjadi peningkatan.

Hal ini jug dapat dilihat dari adanya peningkatan etika bergaul siswa sebesar $40 \%$ setelah diberikan layanan konseling individual pendekatan client centered.

\section{Saran}

Berdasarkan hasil penelitian ini dapat disarankan pada beberapa pihak, diantaranya:

1. Bagi pihak sekolah agar lebih mengupayakan sarana untuk mengembangkan kegiatan-kegiatan positif yang mendukung etika dalam pergaulan siswa.

2. Kepada guru pembimbing, hendaknya memperhatikan siswa disekolah terutama dalam etika pergaulannya dan lebih menguatkan melalui kegiatan konsleing terutama dalam konseling individual. 
3. Bagi siswa, diharapkan lebih menguatkan etika bergaulnya dan mengikuti layanan-layanan yang diberikan oleh guru pembimbing dengan sungguh-sungguh.

4. Diharapkan kepada orang tua agar lebih memperhatikan pendidikan siswa agar siswa lebih bertanggung jawab terhadap kewajibannya sebagai pelajaran.

5. Bagi peneliti selanjutnya supaya lebih mengembangkan dan memaksimalkan pelayanan dalam berbagai layanan terkhusus layanan konseling individual. Berbagai layanan, diharapkan juga para guru BK disekolah untuk dapat terus berinovasi untuk menciptakan kreasi-kreasi baru dalam layanan konseling, terkhusus konseling individual.

DAFTAR PUSTAKA

Allport. 2004. Faktor-Faktor Yang Mempengaruhi Etika Pergaulan Dalam

(Http:Belajarpaikologi.Com).

Alwi, A. 2012. Pengaruh Pelaksanaan Layanan Bimbingan Kelompok Terhadap Etika Pergaulan Pada Siswa Kelas VII Di SMP ArRahman Medan Helvetia Tahun Ajaran 2013/2014. Medan : Unimed. Skripsi Tidak Di Publikasikan.
Arikunto, Suharsimi. 2010. Prosedur Penelitian.Jakarta : Rineka Cipta.

Arikunto. 1982.

Prosedur Penelitian.Jakarta : Rineka Cipta. Arikunto, 2011. Wawancara Konseling Disekolah. Yogyakarta : C. Andi Offset.

Aunur, 2002. Tinjauan Teoritik Dan Permasalahan Etika. Jakarta: Media Widya

Bertens, K. 2007. Etika. Jakarta : PT. Gramedia Pustaka Utama.

Corey, G. 2010. Teori Dan Praktik: Konseling Dan Psikoterapi. Bandung: PT. Refika Adi Tama. Damayanti Inindiya. 2012. Buku Pintar Panduan Bimbingan Dan Konseling . Yogjakarta: Araska Latipun. 2008. Psikologi Konseling Edisi Ke 3. Malang: UPT Penerbitan Universitas Muhammadiyah Malang.

Menanti, Asih. 2013. Penelitian eksperimen. Medan : Universitas negeri Medan.

Nur, bahdin. 2012. Pedoman Penulisan Karya Ilmia. Jakarta : Kencana.

Widiatmo, Nur. 2005. Sopan Santun Dalam Pergaulan sehari-hari. Jakarta: PT Musi Perkasa Utama.

Willis. 2010. Konseling Individual. Bandung: CV. Alfabeta. 
Prayetno dan Erman Amti. 2004. Dasar-

Dasar Bimbingan dan Konseling.

Jakarta : Rineke Cipta.

Prayetno. 2008. Dasar-Dasar Bimbingan dan Konseling. Jakarta : Rineke Cipta.

Salahuddin, A. 2012. Bimbingan dan Konseling. Bandung: CV Pustaka Setia.

Salam, Barhanuddin. 2002. Etika Individu

Pada Dasar Filsafat Moral. Jakarta: Rineka Cipta.

Sjarkawi. 2006. Etika Profesi. Jakarta: Media Widya.

Tim Dosen Unimed. 2016. Pedoman Penulisan Skripsi Fakultas Ilmu Pendidikan. Medan: Unimed

Uno, R. 2009. Buku Pintar Etiket untuk remaja. Jakarta: PT. Gramedia 